\title{
Effect of melatonin supplementation to the maturation media on in vitro cumulus cells expansion and nuclear maturation rates of buffalo oocytes
}

\author{
Sherief M. Shamiah ${ }^{1}$, Asmaa A. Fathy ${ }^{2}$, Emad A. Abdelaziz ${ }^{1}$ and Wael M. Nagy ${ }^{1}$ \\ ${ }^{1}$ Animal Production Research Institute, Ministry of Agriculture, Giza, Egypt. \\ ${ }^{2}$ Animal Production Department, faculty of Agriculture, Menoufia University, Egypt
}

\begin{abstract}
The aim of this study is to determine the effect of the melatonin addition to the maturation medium (MM) on in vitro maturation of buffalo oocytes (IVM). Maturation is evaluated by the cumulus cells expansion and nuclear maturation. The cumulus oocyte complexs (COCs) were harvested by aspiration of antral follicles $(2-8 \mathrm{~mm}$ diameter) of slaughter buffalo ovaries, COCs with homogeneous cytoplasm and at least three layers of cumulus cells were selected. The COCs were incubated for $24 \mathrm{~h}$ in TCM-199 medium with melatonin (10, 30 or 50ng/ml) or without addition (control). After $24 \mathrm{~h}$ in culture media, the maturation rate of oocytes was determined by evaluating the expansion degree of the cumulus-oocyte complex (COCs) in each treatment, then classified into: fully expanded, partially expanded or not expanded, and by evaluation stages of oocyte nuclear maturation $(\mathrm{GV}$, GVBD, MI, MII or degenerated). Results illustrate that supplementation maturation media with 10 and 30, 50 $\mathrm{ng} / \mathrm{ml}$ melatonin resulted in increasing the cumulus cell expansion of buffaloes oocytes by $86.4,82.3,83.2 \%$, respectively, as compared with oocytes cultured with melatonin - free medium (73.3\%), The respective differences were significant. Majority of this improvement in the expansion rates of oocytes was observed in the rate of fully expanded oocytes, On the contrary, the rate of immature (unexpanded) oocytes incubated in melatonin-free medium was significantly $(\mathrm{P}<0.01)$ higher $(26.7 \%)$ than those incubated in maturation media with 10 or 30 or 50 $\mathrm{ng} / \mathrm{ml}$ melatonin $(13.8,17.7,16.9 \%$, respectively). Moreover, results indicated that addition of melatonin to the maturation medium significantly improved the percentage of oocytes of first polar body (matured to MII) as compared with those incubated without melatonin, the highest percentage of those oocytes was obtained with 10 $\mathrm{ng} / \mathrm{ml}$ melatonin ( $\diamond \wedge . \vee \%)$, however, the least percentage was in those oocytes cultured with melatonin - free medium (48.6\%) with significant differences $(\mathbf{P}<\mathbf{0 . 0 5})$. On the other side, the percentage of oocytes of GVBD, MI or degenerated stages did not significantly affected with melatonin addition $(10.30 \mathrm{or} 50 \mathrm{ng} / \mathrm{ml})$ to culture media as compared with those cultured without melatonin medium. It could be concluded that addition of melatonin to the MM improved cumulus expansion and nuclear maturation rate of buffalo oocytes.
\end{abstract}

Key words: Buffalo, IVM, oocyte maturation, melatonin.

\section{Introduction}

As a matter of fact, buffaloes in Egypt represent the main source of milk and meat production. However, their reproductive potentially is still beyond optimum. Efforts have been initiated to improve the reproduction potential of these animals using modern biotechnologies such as., artificial insemination, invitro maturation, fertilization and embryo transfer.

Oocyte maturation is one of the most important steps for successful in vitro production of bovine embryos (Dieleman et al., 2002). Oocyte in vitro maturation is intended to yield oocytes that normally could complete their first meiotic division to undergo normal fertilization, and would result in a zygote capable of full-term development after embryo transfer (Downs, 1993 and Royere 2006). Cumulus cells are known to play a crucial role during oocyte maturation. Gordon, (2003) reported that cumulus cells during maturation are essential for acquiring developmental competence by oocyte in vitro. Optimal expansion of the cumulus mass appears to be essential for cytoplasmic maturation (Testart et al. 1983, Poeggeler et al, 1993). In bovine, the induction of cumulus expansion prior to fertilization increased the incidence of oocyte penetration (Ball et al. 1983).
However, the in vitro maturation system is not as efficient as in vivo maturation (Hendriksen et al., 2000) because the in vitro handling and culture conditions expose oocytes and embryos to oxidative stress resulting from events such as light, elevated oxygen concentrations and unusual concentrations of metabolites and substrates (Kitagawa et al., 2004., Agrawal et al., 2006 ). Moreover, It has been also speculated that buffalo oocytes / embryos, due to their high lipid content (Boni et al, 1992), are particularly sensitive to the increased oxidative stress that occurs under in vitro conditions (Gasparrini et al, 2003), causing damage effects on cellular structure such as mitochondria and microtubles and could disturbe normal cell function (De Matos and Furnus 2000; Khatir et al. 2005). Therefore, it is important to protect oocytes from oxidative stress during in vitro maturation (IVM).

Melatonin (N-aceyl-5-methoxytryptamine), an indole derivative secreted rhythmically from the pineal gland, has major effects on the reproductive system in mammals (Sirotkin and Schaeffer, 1997; Reiter,1998), acts as a powerful free radical scavenger and likely to be a general promoter of anti-oxidative mechanisms and a potential antioxidant in vitro and in vivo (Reiter, 1998; Tan et al., 2007). Melatonintreated oocytes had a significantly lower level of ROS 
than controls. The presence of melatonin receptors in COCs and its promoting effects on oocyte nuclear and cytoplasmic events, indicate the potentially important roles of this hormone in regulating bovine oocyte maturation (El-Raey et al., 2011).

Melatonin is likely to become the drugs of choice for improving oocytes quality for woman who cannot get pregnant because of poor oocytes quality (Takazuki et al., 2003), as well as., exogenous melatonin has beneficial effects on nuclear and cytoplasmic maturation during porcine IVM (Kang et al., 2008), and increased ratio of vitrified sheep blastocysts developed with melatonin application for 24 and $48 \mathrm{~h}$ in vitro was reported (Abecia et al., 2002). The presence of melatonin receptors inCOCs and its promoting effects on oocyte nuclear and cytoplasmic events, indicate the potentially important roles of this hormone in regulating bovine oocyte maturation. Moreover, the presence of ASMT transcript in COCs suggests the possible involvement of these cells in melatonin biosynthesis (El-Raey et al., 2011).

It is worthy to call into attention, the degree of expansion of cumulus cell mass has been routinely considered in evaluating buffalo oocyte maturation in vitro (Palta and Chauhan, 1998 \& Nandi et al., 2002), and for predicting subsequent in vitro fertilization success (Herrler et al., 1992). In addition, the maximum cumulus expansion and extrusion of first polar body is expected to occur during 22-24h of culture (Nandi et al., 2002).

Therefore, the objective of this study was to evaluate the effects of melatonin supplementation to the maturation medium on the cumulus cells expansion and nuclear maturation of buffaloe oocytes in vitro.

\section{Materials and Methods}

\section{Ovaries collection:}

Buffalo ovaries were collected from Shebin El Kom slaughterhouse and were placed immediately after slaughtering into thermos in phosphate buffer saline (PBS) containing $50 \mu \mathrm{g} / \mathrm{ml}$ gentamycin, and transported to the laboratory in Sakha, Kafr El-Sheikh governorate within $2 \mathrm{~h}$ at $30-34^{\circ} \mathrm{C}$. Thereafter; ovaries were washed twice in phosphate buffer saline to remove any adhering clotted blood. The previous history of the reproductive tract of slaughtered animals was unknown.
The cumulus oocyte complexs (COCs) with dark homogeneous cytoplasm and at least three layers of cumulus cells as described by De Loos et al. (1989) were harvested by aspiration of antral Follicles of 2-8 $\mathrm{mm}$ diameter using an 18-gauge needle attached to 10 $\mathrm{ml}$ syringe. The COCs were examined under a stereomicroscope.

\section{In vitro maturation (IVM) and experimental treatments:}

\section{- Preparation of maturation medium:}

On the day of oocyte investigation, maturation medium was prepared. The maturation media consisted of TCM 199 supplemented with $10 \%$ estrous buffalo serum, $10 \mu \mathrm{g} / \mathrm{ml} \mathrm{FSH}$, and $5 \mu \mathrm{g} / \mathrm{ml}$ $\mathrm{LH}, \quad 1 \mu \mathrm{g} / \mathrm{ml}$ estradiol $17 \beta, 3 \mathrm{~mol} \mathrm{~L}-1$ sodium pyruvate and, $50 \mu \mathrm{g} / \mathrm{ml}$ gentamycin sulfate. The maturation medium was supplemented with either 0 or 10 or 30 or $50 \mathrm{ng} / \mathrm{ml}$ Melatonin. The medium was adjusted to $\mathrm{pH}$ of 7.2-7.4 and osmolarity level of 280$300 \mathrm{mOsmol} / \mathrm{kg}$ and filtered by $0.22 \mu \mathrm{m}$-millipore filter. (All chemicals and supplementations were purchased from sigma chemical Co).

About $200 \mu \mathrm{l}$ from each prepared maturation medium was placed into sterile Petri dish and covered by sterile mineral oil. Before oocytes were placed in culture dish, these dishes were incubated in $\mathrm{CO} 2$ incubator $(5 \% \mathrm{CO} 2)$ at $39^{\circ} \mathrm{C}$ and high humidity for one hour at least for equilibration.

\section{- Oocytes maturation:}

The cumulus oocyte complexes were rinsed three times in one of the intended maturation media before culturing in that medium, and incubated in groups of 10-15 oocytes in a $100 \mu 1$ droplet of each culture maturation medium. The droplets were covered with mineral oil in $35 \mathrm{~mm}$ dish and incubated for $24 \mathrm{~h}$ at $38.5^{\circ} \mathrm{C}$ in an atmosphere of $5 \% \mathrm{CO} 2$ in humidified air.

\section{Evaluation of oocyte maturation:}

\section{A. Oocyte expansion:}

After $24 \mathrm{~h}$ in culture, the expansion degree of the cumulus-oocyte complex (COCs) in each treatment of maturation medium was determined to evaluate the efficiency of each medium which was classified as follow:

- Fully expanded (all cumulus cells were loosened)

- Partially expanded (the outer layer of cells was loosened) or

- Not expanded. (As shown in Fig. 1 )

\section{Oocyte recovery:}




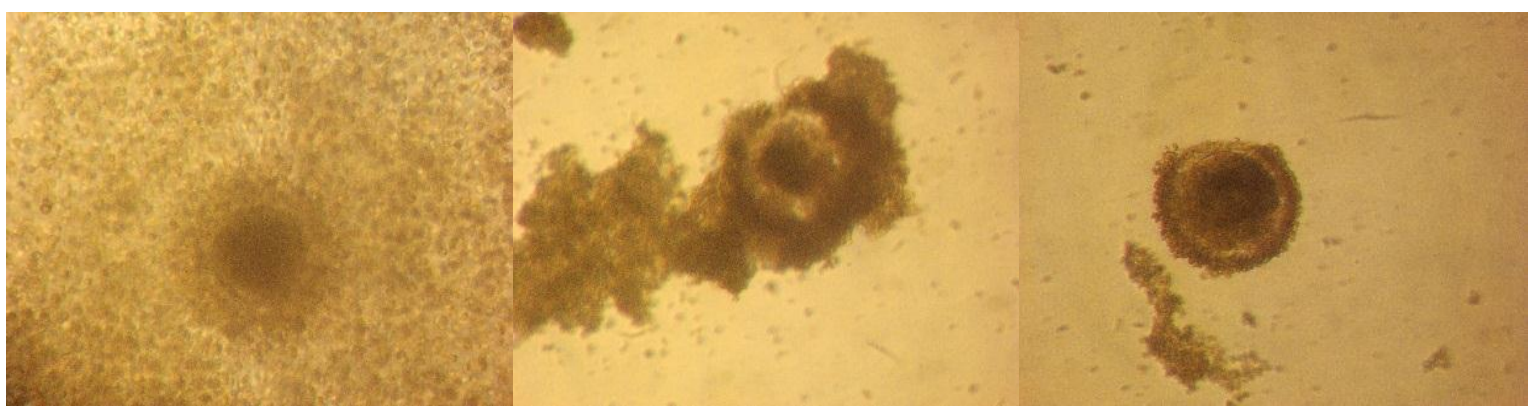

(A)

A; fully expanded,

(B)

B; partially expanded,
(C)

Figure 1. Grades of cumulus cell expansion in COCs after $24 \mathrm{~h}$ incubation in maturation media.

\section{B. Evaluation of oocyte nuclear maturation}

At the end of maturation period, COCs were removed from the maturation medium and the cumulus cells were removed from the oocytes,.

Fixation of the oocytes was carried out by placing the slides in a fresh mixture of acetic acid: ethanol (1:3) overnight (Sun et al., 2001). Oocytes were then stained with $1 \%(\mathrm{w} / \mathrm{v})$ aceto-orcein. for a few minutes and washed by aceto-glycerol (3:1). Both low power and oil immersion were used for detailed examination. Oocytes were categorzed as follows:

\section{Criteria of nuclear maturation:}

After maturation of the oocytes, they were categorized as follows:

a. Germinal vesicle (GV): Inter phase chromosomes enclosed within a nuclear membrane.

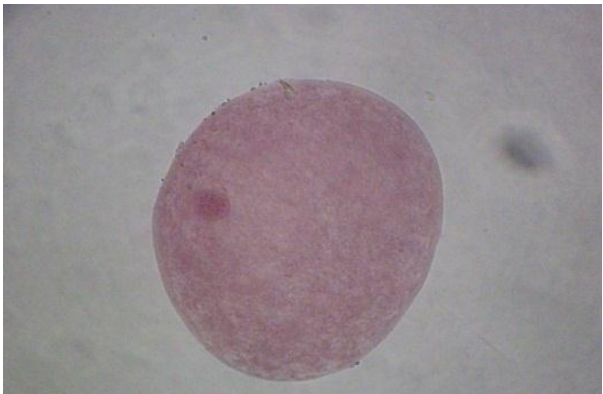

(A)

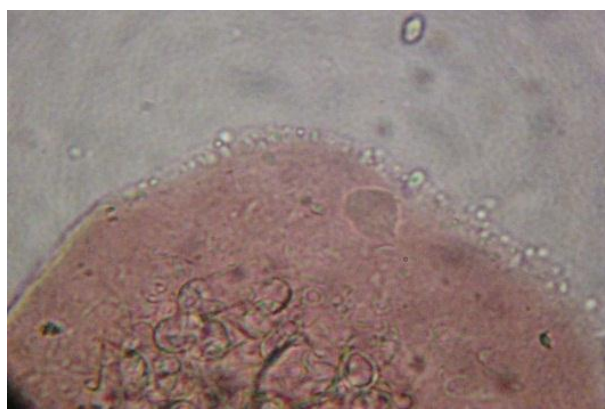

(C)

A; Germinal vesicle stage $(\mathrm{GV})$ C; Metaphase I b. Germinal vesicle breakdown (GVBD): An absence of a visible nuclear membrane and chromatin condensation characterized by a cluster of DNA material without individual chromosomes.

c. Metaphase I (MI): Chromosomes were body.

d. Metaphase II (MII): One the larger group of chromosome formed an equatorial plate and the remaining chromosome are highly condensed or had extruded a polar body (mature oocyte).

- e. Degenerated: Oocytes were vacuolated or had scattered or highly condensed chromatin. (As shown in Fig. 2 ) condensed in pairs and without detected polar

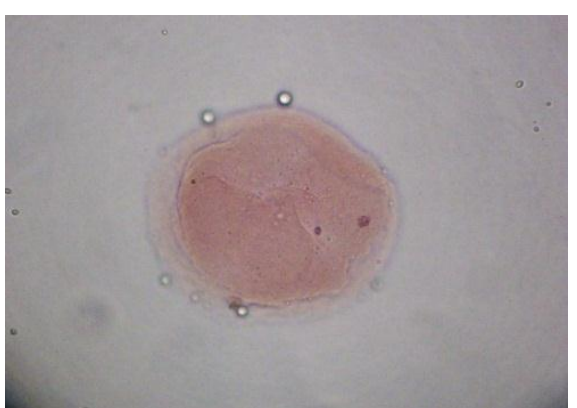

(B)

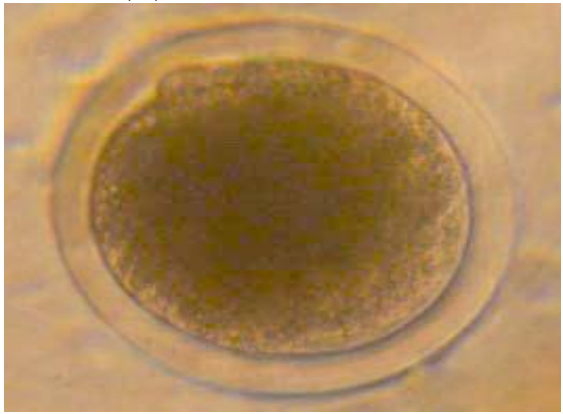

(D)
B;Gerlminal vesicle breakdown (GVBD)

D; Metaphase II.

Fig.2: criteria of nuclear maturation of matured oocytes 


\section{Statistical analysis:}

The obtained data were subjected to one way analysis of variance (ANOVA), followed by Duncan's multiple range test to determine significant difference among means at the $\mathrm{p}=0.05$ level (Duncan, 1955).

\section{Results and Discussion}

The effect of meltonin supplementation on maturation rate of buffaloe oocyte:

\section{- Oocye expansion:}

Results in Table 1 demonstrate that supplementation maturation media with 10 and 30, 50 $\mathrm{ng} / \mathrm{ml}$ melatonin resulted in increasing the cumulus cell expansion of buffaloes oocytes by $86.4,82.3$, $83.2 \%$, respectively, as compared with oocytes cultured with melatonin - free medium $(73.3 \%)$, The respective differences were significant. Majority of this improvement in the expansion rates of oocytes was observed in the rate of fully expanded oocytes, which ranged from 12.2 to $18.9 \%$ as compared with those cultured in melatonin-free medium $(38.8 \%)$. On the contrary, the rate of immature (unexpanded) oocytes incubated in melatonin-free medium was significantly $(\mathrm{P}<0.01)$ higher $(26.7 \%)$ than that incubated in maturation media with 10 or 30 or 50 $\mathrm{ng} / \mathrm{ml}$ melatonin $(13.8,17.7,16.9 \%$, respectively).

Table 1. Effect of melatonin supplementation to maturation medium on expansion rate of buffalo oocytes.

\begin{tabular}{|c|c|c|c|c|c|c|c|c|c|}
\hline \multirow{3}{*}{$\begin{array}{l}\text { melatonin } \\
\text { conc. } \\
(\mu \mathrm{m}\end{array}$} & \multirow{3}{*}{$\begin{array}{c}\text { Total } \\
\text { tested } \\
\text { oocytes }\end{array}$} & \multicolumn{4}{|c|}{ Cumulus } & \multicolumn{2}{|c|}{$\begin{array}{l}\text { expansion } \\
\text { Maturation rate }\end{array}$} & & \\
\hline & & \multicolumn{2}{|c|}{ Full expanded } & \multicolumn{2}{|c|}{$\begin{array}{l}\text { Partially } \\
\text { expanded }\end{array}$} & \multicolumn{2}{|c|}{$\begin{array}{l}\text { (Full+Partially } \\
\text { expanded) }\end{array}$} & \multicolumn{2}{|c|}{ Non expanded } \\
\hline & & No. & $(\%)$ & No. & $(\%)$ & No. & $(\%)$ & No. & $(\%)$ \\
\hline Control & 206 & 80 & $\begin{array}{c}38.8 \pm \\
1.1^{\mathrm{c}} \\
\end{array}$ & 71 & $\begin{array}{c}34.5 \pm \\
0.9^{\mathrm{a}} \\
\end{array}$ & 151 & $\begin{array}{c}73.3 \pm \\
0.9^{\mathrm{a}} \\
\end{array}$ & 55 & $\begin{array}{c}26.7 \pm \\
1 .{ }^{\mathrm{a}} \\
\end{array}$ \\
\hline $10 \mathrm{ng} / \mathrm{ml}$ & 189 & 109 & $\begin{array}{c}57.7 \pm \\
0.9^{\mathrm{a}} \\
\end{array}$ & 54 & $\begin{array}{c}28.6 \pm \\
1 .^{0 \mathrm{c}} \\
\end{array}$ & 163 & $\begin{array}{c}86.4 \pm \\
1.1 \mathrm{c} \\
\end{array}$ & 26 & $\begin{array}{c}13.8 \pm \\
1.1^{\mathrm{c}} \\
\end{array}$ \\
\hline $30 \mathrm{ng} / \mathrm{ml}$ & 198 & 101 & $\begin{array}{c}51.0 \pm \\
0.9^{\mathrm{b}}\end{array}$ & 62 & $\begin{array}{c}31.3 \pm \\
1.1^{\mathrm{b}}\end{array}$ & 163 & $\begin{array}{c}\mathbf{8 2 . 3 \pm} \\
1.2 \mathrm{~b}\end{array}$ & 35 & $\begin{array}{c}17.7 \pm \\
0.7^{\mathrm{b}}\end{array}$ \\
\hline $50 \mathrm{ng} / \mathrm{ml}$ & 178 & 98 & $\begin{array}{c}55.06 \pm \\
1.3^{\mathrm{a}}\end{array}$ & 50 & $\begin{array}{c}28.1 \pm \\
0.9^{c}\end{array}$ & 148 & $\begin{array}{c}\mathbf{8 3 . 2 \pm} \\
0.9 \mathrm{~b}\end{array}$ & 30 & $\begin{array}{c}16.9 \pm \\
1.3^{\mathrm{b}}\end{array}$ \\
\hline
\end{tabular}

a, b and c: Means denoted within the same column with different superscripts are significantly different at $\mathrm{P}<0.001$ ).

The obtained maturation rate in the present study characterized by expansion of COCs is higher than that reported by Totey et al. (1991, 1992 and 1993) (40, 63.6 and $80.0 \%$, respectively), Jainudeen et al. (1993) 47.0\%, Chauhan et al. (1998) $82.0 \%$ and Nandi et al. (2003) $83.0 \%$ in buffaloes. It has been reported that type of medium and supplements which is used for IVM, may influence rate of cumulus cell expansion (Gordon, 2003).

\section{- Nuclear maturation of oocytes}

Generally, the tabulated data Table 2 indicated that addition of melatonin to the maturation medium significantly improved the percentage of oocytes of first polar body (matured to MII) as compared with those incubated without melatonin, the highest percentage of in those oocytes was obtained with 10 $\mathrm{ng} / \mathrm{ml}$ melatonin ( $0 \wedge . \vee \%)$, however, the least percentage was in those oocytes cultured with melatonin - free medium $(48.6 \%)$ with significant differences $(\mathrm{P}<0.05)$.

Table 2. Effect of melatonin supplementation to maturation medium on nuclear maturation of buffalo oocytes in vitro.

\begin{tabular}{|c|c|c|c|c|c|c|c|c|c|c|c|}
\hline \multirow{3}{*}{ Item } & \multirow{3}{*}{$\mathbf{N}$} & \multicolumn{10}{|c|}{ Maturation stage of buffalo oocytes } \\
\hline & & \multicolumn{2}{|c|}{ GV } & \multicolumn{2}{|c|}{ GVBD } & \multicolumn{2}{|c|}{ M I } & \multicolumn{2}{|c|}{ M II } & \multicolumn{2}{|c|}{ Degen. } \\
\hline & & $\mathbf{N}$ & $\%$ & $\mathbf{N}$ & $\%$ & $\mathbf{N}$ & $\%$ & $\mathbf{N}$ & $\%$ & $\mathbf{N}$ & $\%$ \\
\hline Control & 202 & 20 & $\begin{array}{l}9.3 \pm \\
1.8\end{array}$ & 26 & $\begin{array}{c}12.7 \pm \\
1.1\end{array}$ & 38 & $\begin{array}{c}18.7 \pm \\
1.5\end{array}$ & 96 & $\begin{array}{c}48.6 \pm \\
2.8^{\mathrm{b}}\end{array}$ & 22 & $\begin{array}{c}10.8 \pm \\
1.3\end{array}$ \\
\hline $10 \mathrm{ng} / \mathrm{ml}$ & 189 & 16 & $\begin{array}{c}8.4 \pm \\
1.5 \\
\end{array}$ & 16 & $\begin{array}{r}8.5 \pm \\
1.4 \\
\end{array}$ & 29 & $\begin{array}{c}15.0 \pm \\
1.7 \\
\end{array}$ & 110 & $\begin{array}{c}58.7 \pm \\
3.1^{\mathrm{a}} \\
\end{array}$ & 18 & $\begin{array}{c}9.3 \pm \\
1.6 \\
\end{array}$ \\
\hline $30 \mathrm{ng} / \mathrm{ml}$ & 197 & 22 & $\begin{array}{c}10.9 \pm \\
1.3\end{array}$ & 22 & $\begin{array}{c}11.1 \pm \\
1.1\end{array}$ & 37 & $\begin{array}{c}18.5 \pm \\
1.8\end{array}$ & 96 & $\begin{array}{c}49.9 \pm \\
2.8^{\mathrm{b}}\end{array}$ & 20 & $\begin{array}{c}9.6 \pm \\
1.8\end{array}$ \\
\hline $50 \mathrm{ng} / \mathrm{ml}$ & 184 & 20 & $\begin{array}{c}11.0 \\
2.0\end{array}$ & 19 & $\begin{array}{c}10.3 \pm \\
1.4\end{array}$ & 33 & $\begin{array}{c}17.9 \pm \\
1.7\end{array}$ & 92 & $\begin{array}{c}49.8 \pm \\
3.0^{\mathrm{b}}\end{array}$ & 20 & $\begin{array}{l}11.0 \pm \\
1.7^{\mathrm{NS}}\end{array}$ \\
\hline
\end{tabular}

a, b and c: Means denoted within the same column with different superscripts are significantly different at $\mathrm{P}<0.05$. 
It appears that, the percentage of oocytes of GVBD, MI or degenerated stages did not significantly affected with melatonin addition $(10.30$ or $50 \mathrm{ng} / \mathrm{ml})$ to culture media as compared with those cultured without melatonin medium (Table 2).

In conclusion, our results proved that supplementation maturation media with 10 and 30,50 $\mathrm{ng} / \mathrm{ml}$ melatonin resulted in increasing the rates of cumulus cell expansion and nuclear maturation of buffalo's oocytes as compared with those cultured without melatonin addition, this is consistent with the results of Manjunatha et al. (2007) who reported that, addition of melatonin by $10 \mu \mathrm{M}$ to $50 \mu \mathrm{M}$, increase nuclear maturation and transformable embryo of buffalo oocyte in vitro. Leona et al., (2004) stated that melatonin can decrease $\mathrm{H} 2 \mathrm{O} 2$ level in mitochondria, elevates glutathione homeostasis and improves mitochondria performance and activates repairing mechanism of mitochondria genome.

\section{References}

Abecia JA, Forcada F, Zu'ñiga O. 2002. The effect of melatonin on the secretion of progesterone in sheep and on the development of ovine embryos in vitro. Vet Res Commun;26:151-8.

Agrawal A, Tamer MS, Mohamed AB, Jashoman B, Juan GA 2006.Oxidative stressing assisted reproductive techniques. Steril. Fertil. 86:503-512.

Ball, G.D., M.L. Leibfried, R.W., Lenz, R.L., Bavister, B.D. and N.L. First, 1983. Factors affecting successful in vitro fertilization of bovine follicular oocytes. Biol. Reprod. 28: 717-725.

Boni, R., L. Sangella, B. Dale, S. Rovello, Di. Palo and R. Barbieri, 1992. Maturazione in vitro di oociti bufalini: indagine ultrastrtturale. Acta Med. Vet. 38: 15-161.

Chauhan M.S. Singla S.K. Palta P., Manik, R.S., Madan, M.L. 1998. In vitro maturation and fertilization, and subsequent development of buffalo (Bubalus bubalis) embryos, effects of oocyte quality and type of serum. Reprod. Fertil. Dev. 1998;10:173-177.

De Loos, F., C. Van Vliet, P. Van Maurik, and T.A.M. Kruip, 1989. Morphology of immature bovine oocytes. Gamete Res. 24:197-204

De matos DG and CC. Furnus, 2000. The importance of having high glutathione (GSH) level after bovine in vitro maturation on embryo development effect of beta-mercapatoethanol, cysteine and cystine. Theriogenology;53:761-71.

Dieleman, S.J.; Hendriksen, P.J.M.; Viuff, D.; Thomsen, P.D.; Hyttel, P.; Knijn, H.M.; Wrenzycki, C.; Kruip, T.A.M.; Niemann, H.; Gadella, B.M.; Bevers, M.M.; Vos, P.L.A.M. 2002. Effects of in vivo prematuration and in vivo final maturation on developmental capacity and quality of pre-implantation embryos. Theriogenology 57: 5-20.
Downs, S.M., 1993. Factors affecting the resumption of meiotic maturation in mammalian oocytes. Theriogenology 39:65-79

Duncan, D. B. 1955. Multiple Range and Multiple F Tests. Biometrics 11:1.Eno, C. F. 1966. Chicken Manure. Fla. Agr. Exp. Sta. Circ. S-140.

El-Raey M, Geshi M., Somfai T.,Kaneda M.,1 Hiraco M., Abdel- Ghafar A.E., Sosa G.A,,2 MAHMOUD E.A., Abou El-Roos M.E.A. AND Nagali T.,2011 Evidence of melatonin synthesis in the cumulus oocyte complexes and its role in enhancing oocyte maturation in vitro in cattle. Molecular Reproduction \& Development: DOI 10.1002/mrd.21295

Gasparrini B, H. Sayoud, G. Neglia, DG. Matos Donnay and L. Zicarelli, 2003. Glutathione synthesis during in vitro maturation of buffalo (Bubalus bubalis) oocytes: effects of cysteamine on embryo development. Theriogenology. Sep 15;60(5):943-952.

Gordon I 2003. Laboratory production of cattle embryos. Second edition CABI International publishing, Wallingford p. 157.

Hardeland R 2005. Antioxidative protection by melatonin: multiplicity of mechanisms from radical detoxification to radical avoidance. Endocr. 27:119-130

Hendriksen PJ, Vos PL, Steenweg WN, Bevers MM, Dieleman SJ. 2000 Bovine follicular development and its effect on the in vitrocompetence of oocytes. Theriogenology.;53(1):11-20.

Herrler, A., A. Lucas-Hahn, and H. Niemann, 1992. Effects of insulin-like growth factor-I on in vitro production of bovine embryos. Theriogenology 37:1213-1224

Jainudeen, M.R., Takahashi, Y., Nihayah, M. and Kanagawa, H. 1993. In vitro maturation and fertilization of swamp buffalo (Bubalus bubalis) oocytes. Anim. Reprod. Sci. 31:205-212.

Kang, J-T.; Koo, O-J.; Kwon, H-J.; Park, H-J.; Jang, G.; Kang, S-K.; Lee, S-C. 2008. Effects of melatonin on in vitro maturation of porcine oocyte and expression of melatonin receptor RNA in cumulus and granulosa cells. Journal of Pineal Research 46: 22-28.

Kitagawa Y, Suzuki K, Yoneda A, Watanabe T. 2004. Effects of oxygen concentration and antioxidants on the in vitro developmental ability, production of reactive oxygen species (ROS), and DNA fragmentation in porcine embryos. Theriogenology. 62:1186-1197.

Khatir H, Anouassi A, Tibary A. 2005 in vitro and in vivo developmental competence of dromedary (Camelus dromedarius) embryos produced in vitro using two culture systems (mKSOMaa and oviductal cells).Reprod Domest Anim.; 40(3): 245-249.

Leona J, Acuña-Castroviejob D, Sainza RM, Mayoa JC, Tana DX, Reiter RJ 2004. Melatonin and mitochondrial function. Life Sci.75:765-790_ 
Manjunatha BM, Devaraj M, Gupta PSP, Ravindra, JP. Nandi S. 2009. Effect of taurine and melatonin in the culture medium on buffalo in vitro embryo development. Reprod Dom Anim. 44, 12-16.

Nandi, S., B.M Ravindratha, P.S.P. Gupta, H.M Raghu, and P.V. Sarma, 2003. Developmental competence and post-thaw survivability of buffalo embryos produced in vitro: effect of growth factors in oocyte maturation medium and of embryo culture system. Theriogenology. 60:16211631

Nandi, S., B.M, Ravindranatha, P.S.P. Gupta, and P.V. Sarma, 2002. Timing of sequential changes in cumulus cells and first polar body extrusion during in vitro maturation of buffalo oocytes. Theriogenology 57: 1151-1159

Palta, P. and M.S. Chauhan, 1998. Laboratory production of buffalo (Bubalus bubalis) embryos. Reprod. Ferti. Dev. 10:379-391.

Poeggeler B, Reiter RJ, Tan DX, Chen LD, Manchester LC 1993: Melatonin, hydroxyl radical-mediated oxidative damage, and aging: a hypothesis. J Pineal Res, 14(4):151-168.

Reiter RJ. 1998 The ageing pineal gland and its physiological consequences. Bioessays;14:16975.

Royere D., 2006 Oocytes maturation: can oocytes competence be defined? J Gynecol Obstet Biol Record; 35: 2S8-2S13.

Sirotkin, A.V.; Schaeffer, H-J. 1997. Direct regulation of mammalian reproductive organs by serotonin and melatonin. Endocrin154:1-5.

Sun, F.L., Cuaycong, M.H., Elgin, S.C.R. (2001). Long-range nucleosome ordering is associated with gene silencing in Drosophila melanogaster pericentric heterochromatin. Mol. Cell. Biol. 21(8): 2867--2879.

Takazuki A, Nakamura A, Tamura A, Shiamura K, Morioka H (2003).Melatonin as a new drug for improving oocyte_quality. Reprod MedicBiol. 2: 139-144.

Tan DX, Manchester LC, Terron MP, Flores LJ, Reiter RJ. 2007 One molecule, many derivatives: a never-ending interaction of melatonin with reactive oxygen and nitrogen species? J Pineal Res.;42(1):28-42.

Testart J., B. Lassalle, R. Frydman, and JC. Belaisch. (1983). A study of factors affecting the success of human fertilization in vitro. II. Influence of semen quality and oocyte maturity on fertilization and cleavage. Biol Reprod, 28:425-431.

Totey, S.M., C.H. Pawshe, and G.P, Singh, 1993. In vitro maturation and fertilization of buffalo oocytes (Bubalus bubalis): Effects of media, horomens and sera. Theriogenology 39:11531171.

Totey, S.M., G.P Singh, M. Taneja, C.H. Pawshe, and G.P.Talwar, 1992. In vitro maturation, fertilization and development of follicular oocytes from buffalo (Bubalus bubalis). J. Reprod. Fertil. 95:597-607

Totey, S.M., M. Taneja, C.H. Pawshe, G. Singh, G. and G.P. Talwar, 1991. In vitro maturation, fertilization and development of buffalo oocytes. Proceedings of the Third World Buffalo Congress (Varna, Bulgaria) 3:610-617. 